\title{
The Effect of a First Born Child on Work and Childcare Time Allocation: Pre-post Analysis of Australian Couples
}

\author{
George Argyrous ${ }^{1} \cdot$ Lyn Craig $^{2} \cdot$ Sara Rahman $^{1}$
}

Accepted: 22 February 2016

(C) Springer Science+Business Media Dordrecht 2016

\begin{abstract}
This paper uses Australian data from a national representative sample of Australian couples having their first child. Using data from before and after the birth of the child on a range of variables, including economic resources, gender attitudes, workplace flexibility, and availability of non-parental childcare, we first model the factors are associated with the decision to remain in work or not after the birth of the first child. The main finding here is that childbirth has a major impact on mothers' paid work-time, whereas for fathers it has very little impact. Factors that are related to a mother's decision to remain in work or not include the absolute (but not relative) pay of each parent, the father's workplace flexibility, and paid parental leave available to the mother. We then model the factors that govern, for those mothers remaining in paid work, how much paid work they undertake. We find that changing employers is related to mothers' work hours, as are absolute post-birth salaries, as is the relative pay of each partner. As with the decision to work or not, the availability of paid parental leave to the mother is significantly related to the amount of work-time for those mothers that do continue to work. Similarly, the use of external childcare is positively associated with maternal work hours. Finally, we model the factors that determine childcare time allocation and find that for neither parent do pre-birth economic resources significantly affect childcare time, once a decision about basic work patterns has been made. Gender role attitudes affect childcare time decisions, unlike work time decisions.
\end{abstract}

Keywords Labor force participation - Hours of work · Time-use - Childcare time · Employment · Gender

George Argyrous

g.argyrous@anzsog.edu.au

1 The Australia and New Zealand School of Government, Sydney, NSW, Australia

2 The University of New South Wales, Sydney, NSW, Australia 


\section{Introduction}

The birth of the first child represents one of the major transition points in the life course of a family. One particular aspect of childrearing that has to be determined is the amount of time that each parent, in a two-parent household, will devote to childcare, and how much time they will each allocate to other activities, most particularly market work. This paper investigates this issue. It will address the following interrelated questions:

1. What factors influence the decision to remain in work or not after the birth of the first child?

2. For those parents remaining in work, what factors govern the amount of time they allocate to paid work?

3. Given work time decisions, what factors are associated with childcare time allocation?

There is a substantial body of research looking at the impact of childbirth on time-use and the division of labor in the household. This research generally finds that children intensify gender divisions of labour, with women doing the bulk of home care and men doing more of the paid work (Craig and Bittman 2008; Craig and Mullan 2010; Kotila et al. 2013). However, this is not universal, with Swedish research, for example, finding that children are not associated with more intensive gender divisions (Dribe and Stanfors 2009). This implies that the association is mutable, and may vary with policy context as well as with individual and family characteristics.

We contribute to this literature by using information from before and after the childbirth to analyze time-use decisions, and incorporating contextual workplace factors. Detailed understanding of these patterns involves two separate modeling exercises. We first want to understand the factors that may impact on worktime decisions when the first child is born. The outcome of this decision can then be used in a simultaneous equation model to gauge the effect of worktime decisions, and other factors, on childcare time allocation. Argyrous and Rahman (2014) cite evidence from labor supply studies to argue that work-time is determined prior to childcare time allocation decisions, and therefore should be modeled sequentially (see also Pasqua and Mancini 2012).

\section{Work and Childcare: Existing Research}

A central issue for debate over housework divisions more broadly has been the extent to which attitudes to gender roles or the economic resources of each parent within the household dominate time-use decisions. In other words, does gender trump economics? For example, Akerlof and Kranton (2000) developed a widely cited simple game-theoretic model to show that gender identity affects the economics of the household, such that women will do a disproportionate share of housework, despite their economic resources (see also Alvarez and Miles-Touya 2003; Baxter et al. 2008; Bittman et al. 2003).

Others have argued that economic resources play an important role in time-allocation decisions after childbirth. Early theoretical approaches attributed couples' gender divisions of labour to efficient specialisation for joint household benefit (Becker 1991), or to marital bargaining on the basis of each individual's resources (Brines 1994; Mannino and Deutsch 2007). A critical issue for this literature is whether it is the relative or absolute earnings of each member of the couple that have the main influence on time-use decisions. For example Williams (1999), Gupta (2007), and Schober (2013) found that a mother's own 
wage rate is the main determinant of the amount of unpaid work that is done in the home, and by whom it is done. Baxter and Hewitt (2012: 29), on the other hand, conclude using Australian data "that women's housework time is more strongly affected by women's relative earnings than by their absolute earnings".

However, economic considerations are less central to divisions of childcare than to divisions of housework. Whereas many people may wish to avoid doing housework, there is strong subjective emotional impetus for parents to spend time with children. The difference between housework and childcare time is reflected in the consistent evidence from time use surveys that, cross-nationally, the former is trending downwards, and the latter is trending upwards (Craig et al. 2014; Sayer 2005; Sayer et al. 2004a, b). Also, mothers with higher individual resources do not necessarily use them to bargain out of childcare (Deding and Lausten 2006). Employed mothers minimize the impact of their work hours on time with children, cutting back on leisure, sleep and housework, and highly educated women average more childcare than less-educated women (Craig 2006; Guryan et al. 2008; Sayer et al. 2004a, b).

Decision making about household time allocation after first childbirth is therefore likely to be strongly influenced by the two explanatory variables-economic resources and gender role attitudes-which dominate the housework literature. A new baby is financially costly (Bradbury 2008), and both men and women express more traditional attitudes after the birth of their first baby (Baxter et al. 2015). For first time parents, childcare represents an entirely new household activity over which roles and responsibilities by the various members of the household have to be freshly worked out, and gender attitudes to parenting appear more conservative than attitudes to market work and housework time (Craig and Mullan 2011).

However, other critical factors also influence the household division of labor after first childbirth. Among these are whether there are institutional supports for both parents to work, including affordable non-parental childcare (Gornick and Meyers 2003; Kreyenfeld and Hank 2000; Lewis 2009). The use of formal and informal childcare provided by others has been associated with more-equal gender divisions of work and care (Craig and Powell 2013). In some countries, notably the Nordic social democracies, subsidized universal childcare is credited with shifting a large part of the time burden of childcare from the family to the state, and facilitating mothers' employment (Arts and Gelissen 2010; EspingAndersen 2009). In liberal states such as Australia, where childcare is less available and more expensive (Pocock 2005), individual and family economic resources may be more salient, because high income households can afford to use such services more than low income households. This can explain some of the cross-country differences observed by Roeters (2013), who argued that the availability of institutional childcare can reduce the trade-off that might otherwise exist between childcare and paid work time.

Previous research also suggests that workplace constraints may have a differential impact on the ability of mothers and of fathers to choose how they allocate time to childcare and paid employment. Central measures are the availability of parental leave and workplace flexibility to work from home or at different times of the day (Roeters 2013). For example, Hosking et al. (2010), using the same Australian data that we use in this paper, looked specifically at the effect of fathers' leave entitlements immediately after birth on the time they are involved in childcare in the following year and a half. Contrary to studies in Sweden (Haas and Hwang 2008), the US (Nepomnyaschy and Waldfogel 2007) and the UK (Tanaka and Waldfogel 2007), they found "limited support for the view that fathers leave taking at the time of the birth of a child is related to increased involvement of fathers in the care of the child" (2010: 1314). On the other hand, availability and length of 
maternity leave is strongly associated with mothers' time with children and their return-towork decisions (Pronzato 2009; Schober 2012; Whitehouse et al. 2012). Particularly, unpaid maternity leave and flexible working hours are associated with greater likelihood that mothers will return to work after childbirth (Buddelmeyer and Fok 2007).

It is clear that multiple factors potentially influence time allocation to work and childcare by couples having their first child, yet they are rarely examined together. Also, most of the research looking at the impact of childbirth on time-use has used crosssectional analysis (Craig and Bittman 2008; Craig and Mullan 2010; Dribe and Stanfors 2009). These studies compare households with and without children at the same point in time. Cross-sectional analysis does not, however, control for workplace conditions or parental attitudes and resources before the first child was born. Of more interest would be, for each couple, to compare income and other explanatory variables before the first child with time-use afterwards. This pre-post analysis can show how these factors before the first child is born impact on time use after childbirth for each family. Sullivan and Gershuny (2012) do this in relation to housework over a long period of time (1991-2008) for British couples, and Baxter (2009) and Baxter and Hewitt (2012) for Australia. However, there is little analysis of pre-post factors on childcare. Exceptions are Hosking et al. (2010), who as noted above focus on the specific issue of fathers' leave taking on childcare time, and a US study by Yavorsky et al. (2015), which drew on a limited sample of relatively welleducated families.

\subsection{Data and Method}

The paper draws on data from the Australian Longitudinal Survey of Australian Children (LSAC). The LSAC was first conducted in 2004 (Australian Institute of Family Studies 2011), with subsequent waves collected every 2 years. The data are taken from the B cohort, where the subjects of analysis are infants aged 0-1 years of age at the beginning of the study.

The LSAC offers advantages over other datasets, namely that it combines time-diary information for childcare along with labor market, income, and other important variables (unlike the Household Income and Labour Dynamics data, which relies on retrospective recall for measures of childcare time), and is also collected over successive waves, providing pre-post data. Capturing both pre-birth and post-birth variables allows us to significantly advance research into the gendered time use associated with children.

We use data from LSAC Wave 1 and Wave 1.5. LSAC Wave 1 data are made up of two parts: time-use diary data that focuses on the study child, and a separate dataset of non-time interview data on the child and family, with a strong focus on child well-being. Wave 1.5 was a supplementary wave to capture pre-birth and post-birth information, including the wellbeing of the child since the first interview, mother and partner's employment history, maternity and other leave, and the employment levels of each parent after the birth. The survey also gathered data on policy options that respondents thought could have improved conditions for them, such as maternity leave, flexible hours, access to childcare and the availability of part-time work.

The sample is restricted to heterosexual married or cohabiting first-time parents with a biological child 12 months old or younger. This yields a final sample of 804 couples with weekday time use information.

Our outcome variables are mothers' and fathers' time spent in childcare, and in paid work. Childcare is captured through the time diaries. These are focused on the study child's activities throughout the day, but it is possible to transform the data from the child's time- 
diaries into parental time allocation. The diaries record who is present with the child for each activity and time-period, which allows us to aggregate the time parents take care of their children. We use time that the child spends with each parent, and with both parents (without the presence of other adults) to measure parental childcare.

The final measure is for weekdays and uses an average of the diary data for that particular type of day (the response rate for weekday surveys was $79 \%$ ). We focus on weekdays where the potential 'trade-off' between parents over time-use decisions regarding paid work and childcare are most acute. We recognize, however, that the structuring of time-use between weekdays and weekends is one means to deal with this trade-off that further research may be able to shed light upon.

Paid employment time is captured through survey questions, with parents reporting their usual weekly hours. This measure is better than a daily measure of work, especially in analyzing return-to-work decisions, as those decisions are likely to be made using weekly, rather than daily, considerations.

\subsection{Analysis Plan}

To address our questions we conduct two separate modeling exercises. We first want to understand the factors that may impact on worktime decisions when the first child is born. The outcome of this decision can then be used in a simultaneous equation model to gauge the effect of worktime decisions, and other factors, on childcare time allocation.

There are two work decisions that parents have to make after birth that constitute their labour supply: their employment status (to be employed or not) and if employed, how many hours to work. Therefore, to assess the impact of childbirth on labour supply, we use a Heckman selection correction model. This model is appropriate because a significant proportion of women do not report any paid worktime after childbirth. A Heckman model deals with this issue because it first models the factors that lead some parents to exit the labor market, and then for those who remain in the labor market, it models the factors that regulate work hours. The Heckman model has also been used by Schober (2013) to model the selection effect of parenthood on paid work. Indeed, one of the most popular applications of the Heckman selection model is in labour supply (Smith and Stelcner 1988; Glass and Nath 2006). By correcting for selection bias that causes certain types of people to enter or stay in the workforce, elasticities of labour relative to other factors can be properly estimated.

Work decisions taken after the first child is born will affect the childcare time that mothers and fathers each perform. We therefore also construct a simultaneous equation model (SEM) to analyse each parent's childcare time allocation as dependent on the other partner's childcare time, their own and their partner's work time, in addition to a range of other individual and household level variables that past research has identified as important to childcare time allocation decisions. The use of SEM to model time allocation decisions, especially in relation to childcare, has now become widespread (see for example Bloemen et al. 2010; Bloemen and Stancanelli 2014; Pasqua and Mancini 2012; Argyrous and Rahman 2014). This modeling approach recognizes that

'the decision by a mother to spend a certain amount of time performing childcare activities may interact with the mother's decision to allocate time to paid work (and other activities). Fathers may make similar decisions. Furthermore, each person's decisions may also be made with reference to his or her partner's time-use decisions. 
Due to these possible interaction and feedback effects, some time-use decisions need to be estimated from the data simultaneously' (Argyrous and Rahman 2014: 7).

In these multivariate analyses, we control for a number of theoretically relevant factors, discussed above, that might influence parental childcare and paid work time. Central among these are economic resources and gender role attitudes.

We include absolute and relative income. Data on income prior to birth is only available in income categories for each partner, and from these categories we group couples according to the degree to which either the male or the female earns more or less than their respective partner. This produces the following 5-point scale:

- Mother's income is 2 or more categories high than the father's

- Mother's income is 1 category higher than the father's

- Partners are in the same pay category

- Father's income is 1 category higher than the mother's

- Father's income is 2 or more categories high than the mother's

\subsubsection{Gender-Role Attitudes}

Gender-role attitudes have usually been measured by directly asking parents questions about who they feel should have primary responsibility for various household responsibilities (e.g. Renk et al. 2003; Schober 2013). However, such attitudinal questions were not asked as part of the pre-birth LSAC data collection. Past research confronting this problem used a range of proxy variables for gender attitudes, such as marital status (Baxter et al. 2008). In our data, parents were asked, following childbirth, whether they felt the amount of childcare they were undertaking was a 'fair' distribution of work. We compared this to the actual amount of childcare each parent was undertaking. We constructed dummy variables for whether each parent has traditional or non-traditional gender attitudes based on whether they thought they did a fair share of the childcare, compared to the actual share of childcare they performed (see Table 1). By relating each parent's attitudes to the actual tasks they are undertaking, this method arguably improves upon asking in the abstract who parents believe should have primary responsibility for various household tasks.

Table 1 Construction of gender role attitudes variable

\begin{tabular}{|c|c|c|c|c|c|c|}
\hline \multirow{3}{*}{$\begin{array}{l}\text { Relative } \\
\text { childcare time }\end{array}$} & \multicolumn{6}{|c|}{ Parent's perception } \\
\hline & \multicolumn{3}{|l|}{ Mother } & \multicolumn{3}{|l|}{ Father } \\
\hline & $\begin{array}{l}\text { Less than } \\
\text { fair share }\end{array}$ & Fair share & $\begin{array}{l}\text { More than } \\
\text { fair share }\end{array}$ & $\begin{array}{l}\text { Less than } \\
\text { fair share }\end{array}$ & Fair share & $\begin{array}{l}\text { More than } \\
\text { fair share }\end{array}$ \\
\hline $\begin{array}{l}\text { Mother does } \\
\text { more than the } \\
\text { father }\end{array}$ & $\begin{array}{l}\text { Traditional } \\
\text { (5) }\end{array}$ & $\begin{array}{l}\text { Traditional } \\
(260)\end{array}$ & $\begin{array}{l}\text { Non- } \\
\text { traditional } \\
(393)\end{array}$ & $\begin{array}{l}\text { Non- } \\
\text { traditional } \\
(166)\end{array}$ & $\begin{array}{l}\text { Traditional } \\
\quad(426)\end{array}$ & $\begin{array}{l}\text { Traditional } \\
\text { (56) }\end{array}$ \\
\hline $\begin{array}{l}\text { Parents do } \\
\text { equal amounts }\end{array}$ & $\begin{array}{l}\text { Traditional } \\
\text { (1) }\end{array}$ & $\begin{array}{l}\text { Non- } \\
\text { traditional } \\
(35)\end{array}$ & $\begin{array}{l}\text { Non- } \\
\text { traditional } \\
(27)\end{array}$ & $\begin{array}{l}\text { Non- } \\
\text { traditional } \\
(14)\end{array}$ & $\begin{array}{l}\text { Non- } \\
\text { traditional } \\
(44)\end{array}$ & $\begin{array}{l}\text { Traditional } \\
\text { (5) }\end{array}$ \\
\hline $\begin{array}{l}\text { Father does } \\
\text { more than the } \\
\text { mother }\end{array}$ & $\begin{array}{l}\text { Traditional } \\
\text { (0) }\end{array}$ & $\begin{array}{l}\text { Non- } \\
\text { traditional } \\
(42)\end{array}$ & $\begin{array}{l}\text { Non- } \\
\text { traditional } \\
(32)\end{array}$ & $\begin{array}{l}\text { Non- } \\
\text { traditional } \\
(12)\end{array}$ & $\begin{array}{l}\text { Non- } \\
\text { traditional } \\
(58)\end{array}$ & $\begin{array}{l}\text { Traditional } \\
\text { (4) }\end{array}$ \\
\hline
\end{tabular}


We also draw on LSAC information relating to workplace conditions:

\subsubsection{Pre-birth Workplace Flexibility}

Respondents were classified as either having or not having pre-birth workplace flexibility. As questions about pre-birth workplace flexibility were not asked, we used data from the Wave 1 survey questions which asked about whether the respondent could change their work hours temporarily or permanently in their post-birth job.

However, Wave 1.5 data includes some information that allows us to adjust the approximation, chiefly questions around changes in employment and some options that allude to inflexible pre-birth workplaces. Therefore, for respondents who did not change jobs we assume that their workplace flexibility before the birth is the same as after the birth. For those who changed jobs, we assumed that they did not have flexibility before the birth. Those who selected options for other questions (detailed in Table 5 of the "Appendix") that alluded to pre-birth workplace flexibility had their values adjusted as necessary.

\subsubsection{Post-birth Workplace Flexibility}

The workplace flexibility variables are generated based on Wave 1 data, from questions regarding each parent's ability to take leave and change their hours. A parent is categorized as either having or not having workplace flexibility, depending on whether they are able to change their hours temporarily or permanently.

\subsubsection{Paid Parental Leave Availability}

Although the questionnaire asks whether parents took paid parental leave around the birth of the child, it does not ask about whether or not it was available to parents. Therefore, parental leave availability is approximated using several assumptions.

- Those who took paid parental leave are categorised as having access to it.

- Those who did not take paid parental leave (including those who took other forms of leave, such as unpaid parental leave) are considered as not having access to it.

- Other questions in the Wave 1.5 questionnaire related to leave ask why parents took a particular type of leave around the birth of the child and capture situations where parents had no access to paid leave

\subsubsection{Paid External Childcare}

A measure of paid external childcare can be constructed using time-diary data, in a similar way to parental childcare. That is, time that the study child spends in non-parental care on the diary day can be summed. However, because data for any given day may be atypical, we opt to use the survey variable for paid external childcare; total weekly external childcare hours as it better represents normal use of paid external childcare.

\subsubsection{As Control Variables}

We include each parent's age and educational qualifications [whether or not they completed high school (Year 12)] in the analysis. Household demographic variables included 
are the region of residence, marital status of the parents (married or cohabiting) and, as an indicator of family wealth, the number of bedrooms in the home. We also included a dummy variable for whether another adult, such as a grandparent or older sibling, was present in the household. Child characteristics used in the analysis are age, and whether they are still breastfed. To some extent these two variables are correlated, but can have different impacts on work and childcare. For example, parents may spend more time doing childcare activities such as teaching and learning with older babies regardless of whether they are still being breastfed.

\subsection{Data Limitations}

There are a number of limitations to the data that are important to the interpretation of the results. The first is that because the time use data are taken at Wave 1 (prior to variables from Wave 1.5 being collected) there may be issues of causality when running regressions on time-use data using Wave 1.5 explanatory variables. However, the variables used from Wave 1.5 in this case mostly refer to pre-birth conditions and therefore this is not a major problem.

An additional concern regarding Wave 1.5 data is the lower response rate of $71 \%$. This reduces the 'effective' samples used in the analysis as some of the couples that meet the sample selection criteria are dropped from the regression analysis (see Tables 3, 4 for the actual sample sizes used in the modeling).

Due to the time use data being primarily focused on the child's activities, we are unable to isolate the time where the parents may be sleeping in the presence of the child, which would not usually be considered as childcare time. As we cannot separate sleep time from "active" childcare that is done when the parents are awake, figures for childcare could be inflated. Conversely, measuring only time that one or both parents, but not others adults, are present with the child may result in lower estimates than childcare time captured via a time-use survey of parents.

That pre-birth income data is only available in categorical form to some extent reduces the efficiency of estimating the relationship between the pre-birth salary and the outcome variables. It also reduces the accuracy of the measure of relative earning power before the birth. These are both hypothesized to be important in affecting post-birth childcare allocation and bargaining between partners (Kiker and Ng 1990; Zick and Bryant 1996; Bloemen and Stancanelli 2008).

\section{Factors Affecting Worktime Decisions of First-Time Parents: The Decision to Work or Not to Work}

We begin by addressing the first of our three main research questions: what factors are associated with parental decisions to remain in work or not following the birth of the first child?

We first provide mean post-birth work hours and change in mean work hours for mothers and fathers over the transition to parenthood (Table 2). These are broken down by key demographic variables to make a preliminary assessment of the factors that might affect each partner's work hours. There is a noticeable lack of variation in fathers' work hours, with very little deviation from the overall mean of $44 \mathrm{~h}$ per week, and little difference between before and after birth. The only important variation is for fathers who 
Table 2 Average post-birth worktime and change in worktime of mothers and fathers

\begin{tabular}{|c|c|c|c|c|}
\hline \multirow[t]{2}{*}{ Variables } & \multicolumn{2}{|c|}{$\begin{array}{l}\text { Mean work hours } \\
\text { per week }\end{array}$} & \multicolumn{2}{|c|}{$\begin{array}{l}\text { Change in mean work } \\
\text { hours (after birth-before } \\
\text { birth) }\end{array}$} \\
\hline & Mothers & Fathers & Mothers & Fathers \\
\hline \multicolumn{5}{|l|}{ Relative pay ratio } \\
\hline Mother 2 or more categories high & 26 & 45 & -17 & 2 \\
\hline Mother 1 category higher & 27 & 42 & -15 & -1 \\
\hline Partners in same pay category & 26 & 45 & -15 & 0 \\
\hline Father 1 category higher & 24 & 45 & -14 & 0 \\
\hline Father 2 or more categories high & 21 & 47 & -12 & 1 \\
\hline \multicolumn{5}{|l|}{ Marital Status } \\
\hline Not married & 21 & 44 & -16 & 1 \\
\hline Married & 25 & 46 & -14 & 0 \\
\hline \multicolumn{5}{|l|}{ Breastfeeding } \\
\hline No & 25 & 46 & -14 & 0 \\
\hline Yes & 25 & 45 & -15 & 0 \\
\hline \multicolumn{5}{|l|}{ Region } \\
\hline Non-metro & 22 & 46 & -15 & 0 \\
\hline Metro & 26 & 45 & -14 & 0 \\
\hline \multicolumn{5}{|l|}{ Mother has Year 12 qualification } \\
\hline No & 25 & 45 & -14 & 1 \\
\hline Yes & 25 & 45 & -14 & 0 \\
\hline \multicolumn{5}{|l|}{ Father has Year 12 qualification } \\
\hline No & 24 & 45 & -14 & 0 \\
\hline Yes & 25 & 46 & -14 & 0 \\
\hline \multicolumn{5}{|l|}{ Other adult present in household } \\
\hline Yes & 25 & 45 & -14 & 0 \\
\hline No & 25 & 44 & -15 & 0 \\
\hline \multicolumn{5}{|l|}{ Study child's gender } \\
\hline Female & 25 & 46 & -14 & 0 \\
\hline Male & 25 & 45 & -14 & 1 \\
\hline \multicolumn{5}{|l|}{ Mother's gender attitudes } \\
\hline Traditional & 25 & 45 & -15 & 0 \\
\hline Non-traditional & 25 & 46 & -14 & 0 \\
\hline \multicolumn{5}{|l|}{ Father's gender attitudes } \\
\hline Traditional & 25 & 45 & -14 & 0 \\
\hline Non-traditional & 25 & 46 & -15 & 0 \\
\hline \multicolumn{5}{|c|}{ Mother's post-birth workplace flexibility } \\
\hline Not flexible & 24 & 44 & -16 & -1 \\
\hline Flexible & 25 & 46 & -14 & 1 \\
\hline \multicolumn{5}{|c|}{ Father's post-birth workplace flexibility } \\
\hline Not flexible & 26 & 46 & -14 & 0 \\
\hline Flexible & 25 & 45 & -14 & 0 \\
\hline Mother's pre-birth workplace flexi & & & & \\
\hline
\end{tabular}


G. Argyrous et al.

Table 2 continued

\begin{tabular}{|c|c|c|c|c|}
\hline \multirow[t]{2}{*}{ Variables } & \multicolumn{2}{|c|}{$\begin{array}{l}\text { Mean work hours } \\
\text { per week }\end{array}$} & \multicolumn{2}{|c|}{$\begin{array}{l}\text { Change in mean work } \\
\text { hours (after birth-before } \\
\text { birth) }\end{array}$} \\
\hline & Mothers & Fathers & Mothers & Fathers \\
\hline Not flexible & 23 & 45 & -18 & 0 \\
\hline Flexible & 26 & 46 & -12 & 1 \\
\hline \multicolumn{5}{|c|}{ Father's pre-birth workplace flexibility } \\
\hline Not flexible & 25 & 46 & -14 & 1 \\
\hline Flexible & 25 & 45 & -14 & 0 \\
\hline \multicolumn{5}{|c|}{ Mother changed employers } \\
\hline No & 26 & 46 & -13 & 1 \\
\hline Yes & 19 & 45 & -19 & -1 \\
\hline \multicolumn{5}{|c|}{ Mother changed jobs } \\
\hline No & 25 & 45 & -13 & 0 \\
\hline Yes & 24 & 47 & -18 & 2 \\
\hline \multicolumn{5}{|c|}{ Mother's pre-birth availability of paid parental leave } \\
\hline No & 18 & 46 & -17 & 1 \\
\hline Yes & 26 & 45 & -14 & 0 \\
\hline \multicolumn{5}{|c|}{ Father's pre-birth availability of paid parental leave } \\
\hline No & 23 & 45 & -15 & 0 \\
\hline Yes & 27 & 46 & -12 & 1 \\
\hline \multicolumn{5}{|c|}{ Mother's pre-birth weekly salary } \\
\hline$<\$ 299$ & 15 & 44 & -7 & 0 \\
\hline$\$ 300-\$ 499$ & 19 & 44 & -13 & 1 \\
\hline$\$ 500-\$ 699$ & 23 & 45 & -15 & 0 \\
\hline$\$ 700-\$ 999$ & 24 & 46 & -16 & 0 \\
\hline$\$ 1000-\$ 1499$ & 29 & 45 & -14 & 0 \\
\hline$>\$ 1499$ & 36 & 49 & -12 & 1 \\
\hline \multicolumn{5}{|c|}{ Father's pre-birth salary } \\
\hline$<\$ 299$ & 14 & 33 & -24 & 2 \\
\hline$\$ 300-\$ 499$ & 22 & 44 & -16 & 2 \\
\hline$\$ 500-\$ 699$ & 24 & 44 & -12 & 0 \\
\hline$\$ 700-\$ 999$ & 24 & 45 & -15 & 0 \\
\hline$\$ 1000-\$ 1499$ & 26 & 45 & -15 & -1 \\
\hline$>\$ 1499$ & 28 & 50 & -12 & 2 \\
\hline \multicolumn{5}{|c|}{ Mother's pre-birth usual weekly work hours } \\
\hline$<10$ & 15 & 44 & 10 & 2 \\
\hline $10-19$ & 12 & 46 & -2 & 2 \\
\hline $20-29$ & 20 & 43 & -6 & -1 \\
\hline $30-34$ & 18 & 44 & -14 & 1 \\
\hline $35-39$ & 24 & 45 & -13 & 1 \\
\hline $40-49$ & 28 & 45 & -17 & -1 \\
\hline$>50$ & 32 & 51 & -23 & 1 \\
\hline
\end{tabular}


Table 2 continued

\begin{tabular}{|c|c|c|c|c|}
\hline \multirow[t]{2}{*}{ Variables } & \multicolumn{2}{|c|}{$\begin{array}{l}\text { Mean work hours } \\
\text { per week }\end{array}$} & \multicolumn{2}{|c|}{$\begin{array}{l}\text { Change in mean work } \\
\text { hours (after birth-before } \\
\text { birth) }\end{array}$} \\
\hline & Mothers & Fathers & Mothers & Fathers \\
\hline \multicolumn{5}{|c|}{ Father's usual weekly work hours } \\
\hline$<10$ & 31 & 24 & -1 & 19 \\
\hline $10-19$ & 23 & 22 & -15 & 8 \\
\hline $20-29$ & 24 & 28 & -10 & 2 \\
\hline $30-34$ & 20 & 35 & -17 & 3 \\
\hline $35-39$ & 27 & 40 & -11 & 3 \\
\hline $40-49$ & 24 & 45 & -14 & 0 \\
\hline$>50$ & 25 & 53 & -16 & -2 \\
\hline Total & 25 & 45 & -14 & 0 \\
\hline
\end{tabular}

worked very few hours before birth, who have higher work hours post-birth. For mothers, on the other hand, we see substantial variation, especially in relation to relative pay, changes in employer, education level and their own pre-birth salary. Similarly, for those parents who do continue to work after the birth of the first child, the mean change in mothers' work hours was $-14 \mathrm{~h}$, whereas for fathers it was a slight increase of $0.3 \mathrm{~h}$. These results correspond with those of Breunig et al. 2012, using other Australian data (HILDA), who found that fathers' work time is exogenous, whereas the mother's labour supply is much more responsive to the presence or absence of children.

Detailed understanding of these patterns involves two separate modeling exercises. We first want to understand the factors that may impact on worktime decisions when the first child is born. The outcome of this decision can then be used in a simultaneous equation model to gauge the effect of worktime decisions, and other factors, on childcare time allocation.

We conduct a Heckman model for only mothers' worktime, as the descriptive statistics in Table 2 indicate that a selection process does not affect fathers' worktime decisions. Out of a total of 752 mothers who were working before the birth of their first child, $212(28 \%)$ were not working after the birth at the time of the survey. In contrast only $19(2.3 \%)$ of the 804 pre-birth working fathers exited the labor market. Thus, there seems to be an overriding gender-related factor dominating decision-making when the first child is born, which is that the father does not leave employment. Hence, a Heckman model is not appropriate for analyzing fathers' decisions to remain in work or not, as so few exit the labor market.

The results of the Heckman modeling are presented in Table 3.

Looking first at the selection into work model (the lower panel in Table 3), we see that a small set of factors affect whether a new mother remains in the workforce or not. Each parent's absolute salary pre-birth is significantly related to labor force participation of the mother. The signs of this relationship are in the expected direction: fathers' higher salary reduces the likelihood of the mother working after childbirth, whereas mothers' higher salary increases her likelihood of working. On the other hand, parents' relative salaries prebirth do not have any relationship with whether or not mothers remain in work. This suggests that families may base decisions around a desired target family income level, rather than on which of them contributes a higher amount in comparative terms. 
Table 3 Heckman selection model result

\begin{tabular}{|c|c|c|c|c|}
\hline \multirow[t]{3}{*}{ Independent variables } & \multicolumn{4}{|c|}{ Dependent variables } \\
\hline & \multicolumn{2}{|c|}{ Mother's post-birth work hours } & \multicolumn{2}{|c|}{$\begin{array}{l}\text { Mother's change in working } \\
\text { hours (after birth-before birth) }\end{array}$} \\
\hline & $\begin{array}{l}\text { Regression } \\
\text { coefficients }\end{array}$ & $\begin{array}{l}\text { Standardized } \\
\text { coefficients }\end{array}$ & $\begin{array}{l}\text { Regression } \\
\text { coefficients }\end{array}$ & $\begin{array}{l}\text { Standardized } \\
\text { coefficients }\end{array}$ \\
\hline \multicolumn{5}{|l|}{ OLS regression model } \\
\hline Constant & -1.33 & & -1.63 & \\
\hline Relative pre-birth salary & & & 0.08 & 0.01 \\
\hline Relative post-birth salary & $0.01 * * *$ & 0.22 & & \\
\hline Mother's post-birth salary & $0.01 * * *$ & 0.25 & $0.01 * * *$ & 0.16 \\
\hline Father's post-birth salary & $>0.01 * *$ & -0.11 & 0.00 & -0.02 \\
\hline Father's post-birth work hours & $-0.10 * *$ & -0.09 & & \\
\hline Father's pre-birth work hours & -0.16 & -0.01 & $-1.52 * *$ & -0.09 \\
\hline Change in father's work hours & & & $-0.11 * *$ & -0.08 \\
\hline Mother's pre-birth work hours & $2.34 * * *$ & 0.20 & $-4.68 * * *$ & -0.37 \\
\hline $\begin{array}{l}\text { Mother's post-birth workplace } \\
\text { flexibility }\end{array}$ & 0.84 & 0.02 & 0.92 & 0.02 \\
\hline $\begin{array}{l}\text { Father's post-birth workplace } \\
\text { flexibility }\end{array}$ & -0.06 & 0.00 & 0.10 & 0.00 \\
\hline $\begin{array}{l}\text { Mother's pre-birth paid parental leave } \\
\text { availability }\end{array}$ & $7.03 * *$ & 0.21 & 7.36 & 0.20 \\
\hline $\begin{array}{l}\text { Father's pre-birth paid parental leave } \\
\text { availability }\end{array}$ & 1.96 & 0.06 & 1.75 & 0.05 \\
\hline Mother changed employers & $-3.11 *$ & -0.07 & -2.56 & -0.05 \\
\hline Mother changed jobs & 0.32 & 0.01 & -0.31 & -0.01 \\
\hline $\begin{array}{l}\text { Mother's gender attitudes }(1=\text { non- } \\
\text { traditional; } 0=\text { traditional })\end{array}$ & 1.01 & 0.03 & 1.09 & 0.03 \\
\hline $\begin{array}{l}\text { Father's gender attitudes }(1=\text { non- } \\
\text { traditional; } 0=\text { traditional })\end{array}$ & -1.21 & -0.04 & -1.08 & -0.03 \\
\hline Mother's age & 0.04 & 0.01 & 0.12 & 0.03 \\
\hline Father's age & 0.06 & 0.02 & 0.04 & 0.01 \\
\hline Total external childcare & $0.15 * * *$ & 0.11 & $0.11 * *$ & 0.08 \\
\hline Year 12 qualifications: mother & 0.58 & 0.01 & 0.56 & 0.01 \\
\hline Year 12 qualifications: father & -1.70 & -0.05 & -1.17 & -0.03 \\
\hline Whether child is still breastfeeding & 0.53 & 0.02 & -0.95 & -0.03 \\
\hline Region $(1=$ metro; $0=$ non-metro $)$ & 0.44 & 0.01 & 1.11 & 0.03 \\
\hline $\begin{array}{l}\text { Marital status }(1=\text { married; } 0 \text { not } \\
\text { married })\end{array}$ & 1.56 & 0.03 & 2.24 & 0.05 \\
\hline \multicolumn{5}{|l|}{ Selection into work model } \\
\hline Constant & -0.52 & & -0.50 & \\
\hline Relative pre-birth salary & 0.07 & 0.07 & 0.10 & 0.25 \\
\hline Mother's pre-birth salary & $0.27 * *$ & 0.27 & $0.30 * * *$ & 0.85 \\
\hline Father's pre-birth salary & $-0.27 * *$ & -0.27 & $-0.29 * *$ & -0.71 \\
\hline Mother's pre-birth work hours & -0.07 & -0.18 & -0.06 & -0.18 \\
\hline Father's pre-birth work hours & 0.05 & 0.09 & 0.04 & 0.08 \\
\hline Mother's pre-birth work flexibility & -0.06 & -0.06 & -0.05 & -0.05 \\
\hline
\end{tabular}


Table 3 continued

\begin{tabular}{|c|c|c|c|c|}
\hline \multirow[t]{3}{*}{ Independent variables } & \multicolumn{4}{|c|}{ Dependent variables } \\
\hline & \multicolumn{2}{|c|}{ Mother's post-birth work hours } & \multicolumn{2}{|c|}{$\begin{array}{l}\text { Mother's change in working } \\
\text { hours (after birth-before birth) }\end{array}$} \\
\hline & $\begin{array}{l}\text { Regression } \\
\text { coefficients }\end{array}$ & $\begin{array}{l}\text { Standardized } \\
\text { coefficients }\end{array}$ & $\begin{array}{l}\text { Regression } \\
\text { coefficients }\end{array}$ & $\begin{array}{l}\text { Standardized } \\
\text { coefficients }\end{array}$ \\
\hline Father's pre-birth work flexibility & $0.19 *$ & 0.19 & $0.19 *$ & 0.19 \\
\hline $\begin{array}{l}\text { Mother's pre-birth paid parental leave } \\
\text { availability }\end{array}$ & $1.03 * * *$ & 1.03 & $1.06 * * *$ & 1.02 \\
\hline $\begin{array}{l}\text { Father's pre-birth paid parental leave } \\
\text { availability }\end{array}$ & 0.09 & 0.09 & 0.10 & 0.10 \\
\hline $\begin{array}{l}\text { Mother's gender attitudes }(1=\text { non- } \\
\text { traditional; } 0=\text { traditional })\end{array}$ & -0.03 & -0.03 & -0.03 & -0.03 \\
\hline $\begin{array}{l}\text { Father's gender attitudes }(1=\text { non- } \\
\text { traditional; } 0=\text { traditional })\end{array}$ & 0.18 & 0.18 & 0.18 & 0.18 \\
\hline Year 12 qualifications: mother & $0.27 *$ & 0.21 & $0.25^{*}$ & 0.20 \\
\hline Year 12 qualifications: father & -0.09 & -0.09 & -0.08 & -0.08 \\
\hline Mother's age & 0.01 & 0.07 & 0.01 & 0.06 \\
\hline Father's age & 0.00 & -0.03 & 0.00 & -0.02 \\
\hline $\begin{array}{l}\text { Marital status }(1=\text { married; } 0 \text { not } \\
\text { married })\end{array}$ & 0.12 & 0.08 & 0.14 & 0.10 \\
\hline Region $(1=$ metro; $0=$ non-metro $)$ & $-0.26^{* *}$ & -0.25 & $-0.26^{* *}$ & -0.25 \\
\hline Whether child is still breastfeeding & $-0.42 * * *$ & -0.43 & $-0.43 * * *$ & -0.44 \\
\hline Study child's age in months & 0.03 & 0.15 & 0.02 & 0.11 \\
\hline Mills lambda & 7.53 & & 5.745 & \\
\hline $\mathrm{N}$ & 699 & & 724 & \\
\hline chi2 & $136 * * *$ & & $145 * * *$ & \\
\hline
\end{tabular}

$* p<0.10 ; * * p<0.05 ; * * * p<0.01$

The workplace flexibility of the mother is not correlated with her workforce participation after childbirth. However, flexibility in the father's workplace is significant: the more flexible the father's workplace, the more likely that the mother will remain in employment. Also of significance is the strong correlation between the paid parental leave available to the mother and her likelihood of remaining in work. Paid parental level appears to be an important factor in maintaining labor force attachment, a result consistent with the analysis of Waldfogel et al. (1999) for the US, Britain, and Japan. Baxter (2009), also using the LSAC data set, found a similar relationship between paid parental leave and the timing of the mother's return to work.

Mothers' education level is also positively associated with the likelihood of remaining in employment, independently of salary. This may be due to higher education being a proxy for occupations where it is more difficult to replace a female employee or which allow for career disruptions, or it could be the desire of the mother to maintain a return on her investment in her own human capital.

The other factors that are associated with the mothers' propensity to remain in work are whether the child is breastfed and the location of the family, with metropolitan mothers less likely to work after birth. It is not immediately clear why living in a metropolitan area 
decreases the probability of remaining in work, but it could relate to the existence of more opportunities to find a job in the future, so that metropolitan women have more confidence to drop out of the labor market in the expectation of being able to re-enter it later. Nonmetropolitan women may be more reluctant to give up a job if this may permanently incapacitate them from finding another job. Alternatively, non-metropolitan women may not have the added problem of long commute times to work and the difficulties this might present for arranging childcare.

We found no evidence that gender attitudes of either mother or father are associated with maternal return to work.

\section{Factors Affecting Worktime Decisions of First-Time Parents: Worktime Decisions}

We now turn to the second research question of work hours for those mothers who stay in workforce. The OLS regression in the top panel of Table 3 presents the factors, for those mothers working at the time of the LSAC survey, that affect the amount of paid work they undertake.

The most interesting finding is that for mothers remaining in the labor market, changing employers is significantly associated with lower work hours. Given the direction of the effect of changing employers on work hours, the results suggest that women are changing employers in order to work fewer hours and/or gain more flexibility. ${ }^{1}$

The OLS regression model also suggests pre-birth work hours is a strong predictor of employed mothers' work hours and of changes in their work hours. Those mothers who worked more pre-birth also work more after birth. But they also experience a much greater reduction in work hours than mothers who did relatively fewer pre-birth work hours, possibly indicating the difficulty of doing both long work hours and childcare.

Mothers' and fathers' absolute post-birth salaries were also significant related to work hours, with mother's salary twice as strong an effect as father's salary, although the sizes of the coefficients are not very large. The importance of absolute earnings is consistent with previous research in other countries (Schober 2013; Smeaton 2006). The relative post-birth salaries of the partners are also significantly related to differences in maternal work hours, with mothers who earn more than their partner also doing more paid work than mothers who earn the same or less than their partner.

As with the decision to work or not, the availability of paid parental leave to the mother is significantly related to the amount of worktime for those mothers that do continue to work. Similarly, the use of external childcare is positively associated with maternal work hours. Each hour of childcare is associated with 15 more minutes of paid work time for the mother. This is an important finding in relation to current policy discussion in Australia, which is targeting the availability of childcare as a crucial factor affecting female labor force participation (Productivity Commission 2014).

Gender role attitudes are not significantly related to work hours (nor to work selection in the Heckman model), which is similar to the findings of Schober (2013), except for their

\footnotetext{
1 It also suggests that some of the women who were not working after childbirth may have wanted to, but lack of job opportunities at the desired level of work hours prevented them. Ideally we would include a variable in the selection model that indicates mothers who could not find a job but wanted one, but this was not available in the LSAC data set.
} 
finding that British women with more egalitarian reduce their work hours less than those with more traditional views.

\section{Factors Affecting Childcare Time Allocation Between Coupled Parents}

We now address the third question: given work time decisions, what factors are associated with childcare time allocation? The results of this modeling are presented in Table 4.

Two separate regression models are presented, with each parent's gender attitudes and workplace flexibility included separately in Model (1), and interaction effects between workplace flexibility and gender attitudes in Model (2), as independent variables. The reason for focusing on this possible interaction is due to recent research showing that parent's work-life balance is bound up with both their own perceptions of their roles and also the scope that their work provides for them to meet these perceptions (Humberd et al. 2015; Reid 2015). For example, workplace flexibility may be available but if parents see their roles as primarily an employed breadwinner, they may not take advantage of this flexibility.

A major difference between the equations for men and for women is the values and significance of the regression constants. For mothers, these are high (around $17.6 \mathrm{~h}$ ) and statistically significant, but not so for fathers $(2.8-3.8 \mathrm{~h})$. This captures the role that most first-time mothers adopt as the primary carer, whereas for fathers, childcare is less time consuming and more variable. This provides symmetry to the results of the worktime modeling above, which suggest new mothers essentially sacrifice worktime commitments, and childbirth makes very little difference to fathers' working time. Thus variations in childcare time around these overall mean amounts occur within a division of labor that is already highly gendered.

The large and statistically significant values for employment status (i.e. employed or not) for both men and women, but particularly for men, also support the view that these prior decisions about work time commitments are crucial to the decisions about childcare. Numbers of hours worked, however, once controlled for employment status, are not associated with either parent's childcare time. Only a father's work hours were statistically associated with his own childcare time, but even here the magnitude of the association is very small (which is similar to findings in previous research, such as Norwegian time-use analysis by Kitterod and Pettersen 2006). It suggests that to engage fathers more in childcare, a strategy that encourages part-time employment status may be more effective than targeting number of work hours as such.

The regression results also suggest that for neither parent do pre-birth economic resources significantly affect childcare time, once a decision about basic work patterns has been made. Neither absolute nor relative pre-birth salaries were associated with either partner's total childcare time.

Gender role attitudes are associated with each parent's own childcare time. Also, fathers' gender attitudes are associated with mothers' childcare time. This contrasts with the lack of significance for gender attitudes in relation to worktime in the previous Sects. 4 and 5. This implies that for first time parents a basic gender-ordered pattern is established around worktime decisions, irrespective of individual gender attitudes, but gender attitudes then affect differences in childcare between partners within the context of fathers' work obligations. 
Table 4 Simultaneous equation model: daily weekday childcare time by parents

Independent variables

Total childcare time $(\mathrm{min})$

(1)

(2)

Mother's childcare

Constant

Mother's post-birth work hours

$\begin{array}{ll}1061 * * * & 1065 * * * \\ 1.1 & 1.2 \\ 0.7 & 0.6 \\ -104 * & -110^{*} \\ -13 & -16 \\ -27 & -27 \\ 11 & \end{array}$

Father's post-birth work hours

Mother's employment status

Mother's pre-birth salary

Father's pre-birth salary

5.9

5.8

Mother's age

$71 *$

$73 *$

Mother has year 12 qualifications

0.0

0.0

Total external childcare (weekly hours)

$-4.5 * * *$

$-4.8 * * *$

Marital status ( $1=$ married; $0=$ not married)

$-100 *$

$-103 *$

Whether child is still breastfeeding

7.7

1.2

Number of bedrooms

$-14$

$-15$

Region ( $1=$ metro; $0=$ non-metro)

$-0.6$

5.0

Study child's age (months)

$-16 * *$

$73 *$

Other adult present in the household

$-88$

Child's gender $(1=$ male; $0=$ female $)$

36

41

Mother's gender attitudes $(1=$ non-traditional; $0=$ traditional $)$

$-80 * *$

Father's gender attitudes $(1=$ non-traditional; $0=$ traditional $)$

$-126 * * *$

Mother's post-birth workplace flexibility

$-19$

Father's post-birth workplace flexibility

$-31$

Mother's gender attitudes $\times$ Workplace flexibility

$\begin{array}{ll} & -102 * * * \\ & -111 * * * \\ -44 & -46 \\ -10 & -4\end{array}$

Mother's pre-birth availability of paid parental leave

Father's pre-birth availability of paid parental leave

Constant

169

Mother's post-birth work hours

Father's post-birth work hours

Father's employment status

$-268 * * *$

$-0.6$

Mother's pre-birth salary

$-0.9$

$-1.4$

Father's pre-birth salary

$-3.3$

$-14.2$

Relative pre-birth salary

$-12.7$

$-0.2$

Father's age

$-0.6$

$-23$

Father has Year 12 qualifications

$-22$

Mother's total childcare (min)

$0.7 * * *$

$0.7 * * *$

Total external childcare

Marital status ( $1=$ married; $0=$ not married)

12.6

11.8

Whether child is still breastfeeding

$-59 * * *$

$-58 * * *$

Number of bedrooms

$-9.7$

$-11.2$ 
Table 4 continued

Independent variables

Total childcare time (min)

(1)

(2)

Region ( $1=$ metro; $0=$ non-metro $)$

$-1.3$

$-4.5$

Study child's age

$4.6 \quad 5.1$

Other adult present in the household

$-24$

$-23$

Child's gender $(1=$ male; $0=$ female $)$

Mother's gender attitudes $(1=$ non-traditional; $0=$ traditional $)$

19

Father's gender attitudes $(1=$ non-traditional; $0=$ traditional $)$

Mother's post-birth workplace flexibility

Father's post-birth workplace flexibility

Mother's gender attitudes $\times$ Workplace flexibility

Father's gender attitudes $\times$ Workplace flexibility

Mother's pre-birth availability of paid parental leave

Father's pre-birth availability of paid parental leave

$\mathrm{N}$

Equation 1: Chi square

Equation 2: Chi square

$* p<0.10 ; * * p<0.05 ; * * * p<0.01$

The significance of gender attitudes also holds when it is interacted with workplace flexibility. Similarly, the flexibility of the father's workplace is positively associated with their childcare time as a main effect. Interestingly, it is only the combination of fathers' gender role attitudes and workplace flexibility that is associated with mothers' childcare time, rather than each of these variables taken separately. Taken together the results suggest that fathers with non-traditional gender attitudes and also workplace flexibility do more childcare, while their partners do less. This result helps reframe the discussion about work-life balance to include fathers, rather than to be seen as 'just' an issue for women. Father's perceptions of their roles, and the opportunities that workplaces make available to them to engage more actively with their children, can be important focal points for allowing both parents to achieve work-life balance.

The use of external childcare was statistically significantly related to childcare time of each parent, but the values of these coefficients are extremely small ( $<5$ daily minutes per each hour of childcare for mothers, $<3$ daily minutes per each hour of childcare for fathers). However, the signs were opposite for each gender. More external childcare seems to relieve mothers of some childcare (see also Kitterod and Pettersen 2006), but for fathers the association is positive. This suggests that formal childcare may impose some small extra obligations on fathers that they may not otherwise have to incur. It is likely they are involved in dropping off or picking up the child.

Results indicate an asymmetry between each parent's childcare time and that of their partner: the amount of childcare time a mother does is not related to her partner's time, whereas fathers do less childcare as their partners do more, consistent with earlier research using adult time diaries (Craig and Powell 2013). This reinforces the notion that the mother's childcare obligations are 'locked in' by prior time allocation decisions, whereas for fathers there is some limited opportunity to adjust childcare time depending on family circumstances. 
Women who are married rather than cohabitating on average do less childcare, and mothers' childcare time declines with the age of the child. That these factors affect mothers' childcare time, but not that of their partner is consistent with previous findings that women's unpaid work and childcare time is more responsive to spouse and family characteristics than is men's (Craig et al. 2015; Sayer 2005).

\section{Conclusion}

This paper draws on pre- and post-birth information to understand the time allocation of first-time parents to work and childcare. This information has been limited in past research, which has relied almost exclusively on cross-sectional analysis. The data allow us to use sequential models for worktime and childcare time decisions, and to assess how a range of economic, attitudinal, workplace, and household variables affect time allocation.

The most obvious conclusion we draw is that first childbirth and its relationship to paid work hours is essentially a 'woman's issue'. Regardless of what the mother may or may not do in relation to employment, the father keeps on working. There is virtually no impact on fathers' labor force status or hours of work. This is despite substantial variation among couples in terms of relative and absolute pay, gender attitudes, childcare use, and workplace flexibility available to each partner. There seems to be a 'default' position among Australian couples that childbirth does not affect the father's work hours; it is the mother's role to make adjustments to her working life. This confirms a large body of prior research and reinforces the need to address the factors that limit a father's ability to change his balance between paid work and childcare. The inability or unwillingness of new fathers to make substantial changes to their paid work commitments constrains the choices that are then available to women to balance their own paid work and childcare. Australia has recently introduced universal paid paternity leave for 2 weeks, but it is not yet clear what impact such relatively small improvements to leave for fathers will have. Future research could investigate this, but unless it changes the fundamental decision about the primary roles each partner assumes when becoming new parents, it is unlikely that such policies will alter in a significant way a move toward more egalitarian childrearing.

Gender role attitudes do not seem to influence whether mothers remain employed, and if so, how many hours they work. Our results suggest that each partner's absolute salary, coupled with structural factors such workplace flexibility, paid parental leave, and childcare availability, are the main determinants of women's workforce participation after the birth of the first child. Workplace flexibility is an important factor in allowing mothers to maintain attachment to the labor market after the birth of their first child. This has important policy implications in an era where women's labor force participation is becoming an important issue. Since the time of the LSAC survey in 2004, the interrelationships between parental leave, workplace flexibility, childcare availability and affordability, and workforce participation have been subject to close scrutiny in Australia (see Productivity Commission 2014 for extensive discussion), and the subject of competing policy proposals from across the political spectrum. If women can remain in the labor market after the birth of a child, they retain skills, income, and other benefits such as superannuation, all of which may make it easier to increase participation levels when the child is older. Similarly, workplaces that make it easier for women to breastfeed and remain in work will increase labor force participation and working hours. 
Acknowledgments This paper was supported by Australian Research Council Discovery Grant DP1093311.

\title{
Appendix
}

\author{
See Table 5.
}

Table 5 Adjustments made for pre-birth workplace flexibility

\begin{tabular}{|c|c|c|}
\hline Question & Response & Adjustment \\
\hline $\begin{array}{l}\text { Which, if any of the following forms of } \\
\text { assistance did you receive at work while you } \\
\text { were pregnant with the study child? }\end{array}$ & $\begin{array}{l}\text { "I was given flexible choices } \\
\text { about leave" OR "I was given } \\
\text { more flexible or shorter } \\
\text { hours" }\end{array}$ & $\begin{array}{l}\text { Mother's pre-birth } \\
\text { workplace } \\
\text { flexibility }=\text { Yes }\end{array}$ \\
\hline $\begin{array}{l}\text { Which of the following best describes why you } \\
\text { didn't take any leave at the time? }\end{array}$ & $\begin{array}{l}\text { "I had a lot of flexibility in my } \\
\text { job and could get by without } \\
\text { taking leave" }\end{array}$ & $\begin{array}{l}\text { Mother's pre-birth } \\
\text { workplace } \\
\text { flexibility }=\text { Yes }\end{array}$ \\
\hline $\begin{array}{l}\text { Which of the following were most important in } \\
\text { your decision to leave work before the birth of } \\
\text { the study child? }\end{array}$ & $\begin{array}{l}\text { "I couldn't get enough } \\
\text { flexibility in my hours" }\end{array}$ & $\begin{array}{l}\text { Mother's pre-birth } \\
\text { workplace } \\
\text { flexibility }=\text { No }\end{array}$ \\
\hline Why did you change jobs? & $\begin{array}{l}\text { "I wanted shorter or more } \\
\text { flexible hours" }\end{array}$ & $\begin{array}{l}\text { Mother's pre-birth } \\
\text { workplace } \\
\text { flexibility }=\text { No }\end{array}$ \\
\hline $\begin{array}{l}\text { Which, if any of the following employment } \\
\text { changes has your partner made since the birth } \\
\text { of your child? }\end{array}$ & $\begin{array}{l}\text { "Taken a job with more } \\
\text { flexibility" }\end{array}$ & $\begin{array}{l}\text { Father's pre-birth } \\
\text { workplace } \\
\text { flexibility }=\text { No }\end{array}$ \\
\hline
\end{tabular}

\section{References}

Akerlof, G. A., \& Kranton, R. E. (2000). Economics and identity. The Quarterly Journal of Economics, 115, $715-753$.

Alvarez, B., \& Miles-Touya, D. (2003). Gender effect on housework allocation: Evidence from Spanish two-earner couples. Journal of Population Economics, 16(2), 227-242.

Argyrous, G., \& Rahman, S. (2014). How does paid work affect who does the childcare? An analysis of the time use of Australian couples. Review of Economics of the Household, 1-16. doi:10.1007/s11150-0149274-5.

Arts, W., \& Gelissen, J. (2010). Models of the welfare state. In F. Castles, S. Leibfried, J. Lewis, H. Obinger, \& C. Pierson (Eds.), The Oxford handbook of the welfare state. Oxford: Oxford University Press.

Australian Institute of Family Studies. (2011). Longitudinal study of Australia children data user guide. Melbourne: Australian Institute of Family Studies.

Baxter, J. (2009). Mothers' timing of return to work by leave use and pre-birth job characteristics. Journal of Family Studies, 15, 153-166.

Baxter, J., Buchler, S., Perales, F., \& Western, M. (2015). A life-changing event: First births and men's and women's attitudes to mothering and gender divisions of labor. Social Forces, 93, 989-1014.

Baxter, J., \& Hewitt, B. (2012). Negotiating domestic labor: Women's earnings and housework time in Australia. Feminist Economics, 19, 29-53.

Baxter, J., Hewitt, B., \& Haynes, M. (2008). Life course transitions and housework: Marriage, parenthood, and time on housework. Journal of Marriage and Family, 70, 259-272.

Becker, G. (1991). A treatise on the family. Cambridge, MA: Harvard University Press.

Bittman, M., England, P., Sayer, L., Folbre, N., \& Matheson, G. (2003). When does gender trump money? Bargaining and time in household work. American Journal of Sociology, 109, 186-214.

Bloemen, H., Pasqua, S., \& Stancanelli, E. (2010). An empirical analysis of the time allocation of Italian couples: Are they responsive? Review of Economics of the Household, 8, 345-369. 
Bloemen, H.G., Stancanelli, E.G. (2008). How do parents allocate time? The effects of wages and income. IZA Discussion Paper No. 3679. Institute for the Study of Labor (IZA), Bonn.

Bloemen, H., \& Stancanelli, E. (2014). Market hours, household work, child care, and wage rates of partners: an empirical analysis. Review of Economics of the Household, 12, 51-81.

Bradbury, B. (2008). Time and the cost of children. Review of Income and Wealth, 54, 305-323.

Breunig, R., Gong, X., \& King, A. (2012). Partnered women's labour supply and child-care costs in Australia: Measurement Error and the child-care price*. Economic Record, 88, 51-69.

Brines, J. (1994). Economic dependency, gender, and the division of labor at home. American Journal of Sociology, 100, 652-688.

Buddelmeyer, H., \& Fok, Y. K. (2007). What determines how long women spend out of the labour force after the birth of a child?. Melbourne: Melbourne Institute of Applied Economic and Social Research.

Craig, L. (2006). Parental education, time in paid work and time with children: An Australian time-diary analysis. The British Journal of Sociology, 57, 553-575.

Craig, L., \& Bittman, M. (2008). The effect of children on adults' time-use: An analysis of the incremental time costs of children in Australia. Feminist Economics, 14(2), 57-85.

Craig, L., \& Mullan, K. (2010). Parenthood, gender and work-family time in USA, Australia, Italy, France and Denmark. Journal of Marriage and Family, 72(5), 1344-1361.

Craig, L., \& Mullan, K. (2011). How mothers and fathers share childcare: A cross-national time-diary comparison. American Sociological Review, 76(6), 834-861.

Craig, L., \& Powell, A. (2013). Non-parental childcare, time pressure and the gendered division of paid work, domestic work and parental childcare. Community, Work and Family, 16(1), 100-119.

Craig, L., Powell, A., \& Brown, J. (2015). Co-resident parents and young people aged 15-34: Who does what housework? Social Indicators Research, 121(2), 569-588.

Craig, L., Powell, A., \& Smyth, C. (2014). Towards intensive parenting? Changes in the composition and determinants of mothers and fathers' time with children, 1992-2006. British Journal of Sociology, 65(3), 555-579.

Deding, M., \& Lausten, M. (2006). Choosing between his time and her time: Paid and unpaid work of Danish couples. Electronic International Journal of Time Use Research, 3(1), 28-48.

Dribe, M., \& Stanfors, M. (2009). Does parenthood strengthen a traditional household division of labor? Evidence from Sweden. Journal of Marriage and Family, 71(1), 33-45.

Esping-Andersen, G. (2009). The incomplete revolution: Adapting to women's new roles. Cambridge: Polity Press.

Glass, J., \& Nath, L. E. (2006). Religious conservatism and women's market behavior following marriage and childbirth. Journal of Marriage and Family, 68, 611-629.

Gornick, J., \& Meyers, M. (2003). Families that work: policies for reconciling parenthood and employment. New York: Russell Sage.

Gupta, S. (2007). Autonomy, dependence, or display? The relationship between married women's earnings and housework. Journal of Marriage and Family, 69(2), 399-417.

Guryan, J., Hurst, E., \& Kearney, M. (2008). Parental education and parental time with children. Journal of Economic Perspectives, 22(3), 23-46.

Haas, L., \& Hwang, P. (2008). The impact of taking parental leave on fathers' participation in childcare and relationships with children: Lessons from Sweden. Community, Work, and Family, 11, 85-104.

Hosking, A., Whitehouse, G., \& Baxter, J. (2010). Duration of leave and resident fathers' involvement in infant care in Australia. Journal of Marriage and Family, 72, 1301-1316.

Humberd, B., Ladge, J. J., \& Harrington, B. (2015). The 'new' dad: Navigating fathering identity within organizational contexts. Journal of Business and Psychology, 30(2), 249-266.

Kiker, B. F., \& Ng, Y. C. (1990). A simultaneous equation model of spousal time allocation. Social Science Research, 19(2), 132-152.

Kitterod, R. H., \& Pettersen, S. V. (2006). Making up for mothers' employed working hours? Housework and childcare among Norwegian fathers. Work, Employment \& Society, 20(3), 473-492.

Kotila, L. E., Schoppe-Sullivan, S. J., \& Kamp Dush, C. M. (2013). Time in parenting activities in dualearner families at the transition to parenthood. Family Relations, 62, 795-807.

Kreyenfeld, M., \& Hank, K. (2000). Does the availability of child care influence the employment of mothers? Findings from western Germany. Population Research and Policy Review, 19, 317-337.

Lewis, J. (2009). Work-family balance, gender and policy. Cheltenham, UK, Northhampton, MA: Edward Elgar.

Mannino, C. A., \& Deutsch, F. M. (2007). Changing the division of household labor: A negotiate process between partners. Sex Roles, 56, 309-324.

Nepomnyaschy, L., \& Waldfogel, J. (2007). Paternity leave and fathers' involvement with their young children. Community, Work, and Family, 10, 427-453. 
Pasqua, S., \& Mancini, A. L. (2012). Asymmetries and interdependencies in time-use between Italian parents. Applied Economics, 44(32), 4153-4171.

Pocock, B. (2005). Work/care regimes: Institutions, culture and behaviour and the Australian case. Gender, Work and Organization, 12(1), 32-49.

Productivity Commission. (2014). Childcare and early childhood learning. Inquiry Report No. 73, Canberra.

Pronzato, C. (2009). Return to work after childbirth: Does parental leave matter in Europe? Review of Economics of the Household, 7, 341-360.

Reid, E. (2015). Embracing, passing, revealing, and the ideal worker image: How People navigate expected and experienced professional identities. Organization Science, 26(4), 997-1017.

Renk, K., Roberts, R., Roddenberry, A., Luick, M., et al. (2003). Mothers, fathers, gender role, and time parents spend with their children. Sex Roles, 48, 305-315.

Roeters, A. (2013). Cross-national differences in the association between parental work hours and time with children in Europe: A multilevel analysis. Social Indicators Research, 110(2), 637-658.

Sayer, L. (2005). Gender, time and inequality: Trends in women's and men's paid work, unpaid work and free time. Social Forces, 84(1), 285-303.

Sayer, L., Bianchi, S., \& Robinson, J. (2004a). Are parents investing less in children? Trends in mothers' and fathers' time with children. American Journal of Sociology, 110(1), 1-43. doi:10.1086/386270.

Sayer, L., Gauthier, A., \& Furstenberg, F. (2004b). Educational differences in parents' time with children: Cross-national variations. Journal of Marriage and Family, 66(5), 1152-1169.

Schober, P. (2012). Parental leave policies and child care time in couples after childbirth. SOEP paper No. 434. Social Science Research Network.

Schober, P. (2013). The parenthood effect of gender inequality: Explaining the change in paid and domestic work when British couples become parents. European Sociological Review, 29(1), 74-85.

Smeaton, D. (2006). Work return rates after childbirth in the UK-trends, determinants and implications: A comparison of cohorts born in 1958 and 1970. Work, Employment \& Society, 20(1), 5-25.

Smith, J. B., \& Stelcner, M. (1988). Labour supply of married women in Canada, 1980. Canadian Journal of Economics, 21, 857.

Sullivan, O. \& Gershuny, J. (2012) Relative human capital resources and housework: a longitudinal analysis. Sociology Working Papers Paper Number 2012-04, Department of Sociology, University of Oxford.

Tanaka, S., \& Waldfogel, J. (2007). Effects of parental leave and work hours on fathers' involvement with their babies. Community, Work, and Family, 10, 409-426.

Waldfogel, J., Higuchi, Y., \& Abe, M. (1999). Family leave policies and women's retention after childbirth: Evidence from the United States, Britain, and Japan. Journal of Population Economics, 12(4), 523-545.

Whitehouse, G., Hosking, A., \& Baird, M. (2012). Returning too soon? Australian mothers' satisfaction with maternity leave duration. Asia Pacific Journal of Human Resources, 46(3), 288-302.

Williams, R. A. (1999). Wage effects on the volume of unpaid work in Nuclear Australian households. Australian Economic Papers, 38(2), 91-105.

Yavorsky, J. E., Kamp Dush, C. M., \& Schoppe-Sullivan, S. J. (2015). The production of inequality: The gender division of labor across the transition to parenthood. Journal of Marriage and Family, 77(3), 662-679.

Zick, C. D., \& Bryant, W. K. (1996). A new look at parents' time spent in child care: Primary and secondary time use. Social Science Research, 25(3), 260-280. 


\section{University Library}

\section{- M M N E R VA A gateway to Melbourne's research publications}

Minerva Access is the Institutional Repository of The University of Melbourne

Author/s:

Argyrous, G;Craig, L;Rahman, S

Title:

The Effect of a First Born Child on Work and Childcare Time Allocation: Pre-post Analysis of Australian Couples

Date:

2017-03-01

Citation:

Argyrous, G., Craig, L. \& Rahman, S. (2017). The Effect of a First Born Child on Work and Childcare Time Allocation: Pre-post Analysis of Australian Couples. Social Indicators Research: an international and interdisciplinary journal for quality-of-life measurement, 131 (2), pp.831-851. https://doi.org/10.1007/s11205-016-1278-5.

Persistent Link:

http://hdl.handle.net/11343/251920 